\title{
Inocentes homicidas: descontinuidades e permanências da violência em Guimarães Rosa e Rubem Fonseca
}

Roberto Círio Nogueira - USP

Resumo:

Estudo de Grande sertão: veredas, de Guimarães Rosa, e dos contos Intestino grosso, "Entrevista", "Feliz Ano Novo", "Mandrake", "O cobrador" e "Os inocentes", de Rubem Fonseca, com o objetivo de mostrar como os episódios narrativos enfocados contêm manifestações de violência que implicam um caráter inocente, em certo sentido, dos personagens que as executam, sendo, portanto, mais preciso classificá-las como monstruosidades do que como ações criminosas, levando-se em conta que a perversidade inerente aos monstros faz parte do não saber que impulsiona seus atos.

Palavras-chave: Guimarães Rosa; Rubem Fonseca; violência

\section{INTRODUÇÃO}

Quando Pero Vaz de Caminha conheceu os habitantes nativos das terras recémdescobertas, relatou ao rei $D$. Manoel: "Senhor, a inocência desta gente é tal que a de Adão não seria maior - com respeito ao pudor." Mal sabia o escrivão que a inocência dessa alteridade autóctone tornar-se-ia um elemento constitutivo da brasilidade, o qual, conjugado com a violência imperialista trazida pelos colonizadores, permearia - além do referido pudor - outros sentimentos e atitudes; tal como se observa nesta afirmação de Guimarães Rosa a seu interlocutor, Günter Lorenz: "A gente do sertão, os homens de meus livros (...) vivem sem consciência do pecado original; portanto, não sabem o que é o bem e o que é o mal. Em sua inocência, cometem tudo o que nós chamamos 'crimes', mas que para eles não o são."1 E também nesta passagem de um conto de Rubem Fonseca: "Há crimes tão inocentes que não somos capazes de classificá-los como tal."2

A partir de tais considerações iniciais, este artigo pretende demonstrar como determinadas manifestações de violência - representadas na prosa de Guimarães Rosa e de Rubem Fonseca - implicam, por parte de seus executores, certa inocência, revelando assim uma das maneiras de ser do homem cordial, cujo conceito - formulado por Sérgio Buarque de Holanda (2007) - é uma das mais conhecidas tentativas de definição da identidade cultural brasileira.

\footnotetext{
1 LORENZ. Diálogo com Guimarães Rosa, p. 58.

${ }^{2}$ FONSECA. Romance negro, Feliz ano novo e outros contos, p. 53.
} 


\section{PARTE I}

A relevância da violência enquanto tema na obra dos escritores citados é algo perceptível desde a composição de dois de seus mais significativos personagens: Riobaldo e o Autor de "Intestino grosso". O narrador-protagonista de Grande sertão: veredas, em seu relato memorialístico ao interlocutor forasteiro, admite que "podia ser: padre sacerdote, se não chefe de jagunços; para outras coisas não fui parido. Mas minha velhice já principiou, errei de toda conta". " $\mathrm{A}$ percepção da dualidade que constitui a essência de sua personalidade encontra ressonância naquele outro personagem, o autor de um livro homônimo ao conto "Intestino grosso" - do qual é protagonista. Segundo ele mesmo diz: "Gente como nós ou vira santo ou maluco, ou revolucionário ou bandido. Como não havia verdade no êxtase nem no poder, fiquei entre escritor e bandido." ${ }^{4}$ Ambos revelam-se analogamente divididos entre condutas conceitualmente contraditórias, como a religiosa e a homicida, já que a primeira se refere ao catolicismo evocado pelas palavras padre e santo - em cujos preceitos fundamentais há um que proíbe o homicídio, ao contrário do que estabelece a jagunçagem, o banditismo (em determinadas circunstâncias) e, inclusive, os procedimentos revolucionários que também se Ihes apresentam como alternativas possíveis à vocação eclesiástica.

O modo como lidam com tal dilema, no entanto, é bem diferente. Riobaldo vivencia a angústia da dúvida, consequência da crise paradigmática que se abate sobre si enquanto narra sua história de vida ao interlocutor forasteiro: "Eu, quem é que eu era? De que lado eu era? Zé Bebelo ou Joca Ramiro?"5 "O jagunço Riobaldo. Fui eu? Fui e não fui. Não fui! - porque não sou, não quero ser. Deus esteja!" ${ }^{\prime \prime}$ Revela-se então uma composição de identidade fragmentária, resultante de uma trajetória de vida dialética que o leva a filiar-se ao bando revolucionário de Zé Bebelo, do qual se torna desertor e, ainda, adversário, ao ingressar no grupo sociopolítico antagônico, o do banditismo jagunço. A tensão causada pela experiência de tais contradições acaba por demandar uma tentativa de conciliá-las ou, pelo menos, compreender melhor o sentido de cada uma. Daí esse misto de herói e bandido tornar-se, quando velho, um contador de histórias.

Algo semelhante ocorre ao protagonista de "Intestino grosso", cujo horizonte abrangia caminhos muito parecidos aos de Riobaldo. O personagem fonsequiano, contudo, apesar de recusar-se a seguir uma direção religiosa ou política qual aquele, deixa sob suspeita a opção exclusiva entre escritor e bandido numa declaração ambígua ao seu entrevistador: "Sempre achei que uma boa história tem que terminar com alguém morto. Estou matando gente até hoje."7 Não há como afirmar indubitavelmente se os assassinatos de sua autoria são, no âmbito do conto, eventos ficcionais ou reais, pois a frase em grifo indica estas duas chaves de leitura: pode se tratar apenas de um autor de romances policiais, cujas estórias têm como mote algum homicídio, ou, então, de um assassino que, sob uma carapuça literária, relata as execuções que pratica tal como os protagonistas-narradores dos demais contos que antecedem "Intestino grosso" na coletânea Feliz Ano Novo.

Diante da impassibilidade do personagem em esclarecer o dilema deixado em aberto infere-se uma diferença substantiva entre si e Riobaldo: somente este é

\footnotetext{
${ }^{3}$ ROSA. Grande sertão: veredas. Edição comemorativa, p. 12.

${ }^{4}$ FONSECA. Contos reunidos, p. 461.

${ }^{5}$ ROSA. Grande sertão: veredas. Edição comemorativa , p. 137.

${ }^{6}$ ROSA. Grande sertão: veredas. Edição comemorativa, p. 197.

7 FONSECA. Contos reunidos, p. 460. (grifo nosso)
} 
perturbado pelo sentimento de culpa decorrente das mortes que causou. Aquele, ao contrário, é capaz de formular até mesmo uma polêmica apologia ao infanticídio como estratégia de redenção da humanidade perante o processo apocalíptico de aquecimento global: "Adote uma árvore e mate uma criança. ${ }^{8}$ Proposta da seguinte maneira explicada:

Meu slogan podia ser, também, adote um animal selvagem e mate um homem. Isso não porque odeie, mas, ao contrário, por amar os meus semelhantes. Apenas tenho medo de que os seres humanos se transformem primeiro em devoradores de insetos e depois em insetos devoradores. Em suma, tem gente demais, ou vai ter gente demais daqui a pouco no mundo, criando uma excessiva dependência à tecnologia e uma necessidade de regimentalização próxima da organização do formigueiro. ${ }^{9}$

Numa espécie de autópsia dos valores disseminados como progressistas pela ideologia civilizadora da modernidade eurocêntrica, esse excerto expõe como monstruosidade máxima o rebaixamento da humanidade à mera condição de uma nuvem de gafanhotos, por exemplo, devido ao consumismo irrefletido das sociedades capitalistas contemporâneas. Considerando-se que tal expectativa só tem se agravado desde a publicação do conto em tela, em 1975, a prática de homicídio - condenada pela modernidade, exceto em casos de legítima defesa - pode vir a ser uma estratégia de sobrevivencia, em vez de crime prescrito por lei.

Delineia-se assim um horizonte possível para a humanidade à beira de um colapso, uma heterotopia conforme ensina Boaventura Santos: "Trata-se (...) de viver a fronteira da sociabilidade como forma de sociabilidade. ${ }^{10} \mathrm{O}$ personagem fonsequiano propõe, portanto, encarar o ser humano sem recalcar o seu lado monstruoso, cujo potencial destrutivo - que ainda pode ser revertido construtivamente - a cultura ocidental sempre procurou eclipsar por trás de discursos ideológicos com os quais se legitimaram grandes catástrofes. ${ }^{11}$ Eclipse que inclusive Riobaldo tenta realizar agregando em sua identidade diversas religiões "para se desendoidecer, desdoidar, ${ }^{12}$ confessando uma necessidade constante de exorcismo. Algo que já não preocupa o outro personagem em questão, cuja identidade parece mais bem resolvida justamente por aceitar o seu lado inevitavelmente perverso, reconhecendo o Mal necessário à emancipação humana dos sistemas opressores criados pela própria humanidade.

Esse recalque do protagonista de Grande sertão: veredas, contudo, não o impede de prezar, às vezes, "o bom regime jagunço"13 - conforme já observara Jaime Ginzburg. ${ }^{14} \mathrm{Em}$ contradição à sua prática religiosa, Riobaldo também alimenta a "noção de que, dentro da jagunçagem, não matar é vergonhoso", ${ }^{15}$ já que "a forma de vida jagunça é sustentada sobretudo pela importância cultural decisiva que assume seu instrumento de sobrevivência, a violência". ${ }^{16}$ A tensão experimentada pelo personagem serve-Ihe então de estímulo para contar sua história em busca "de tornar de algum modo aceitáveis (ou pelo menos mais compreensíveis) situações e problemas que, antes de [a

\footnotetext{
${ }^{8}$ FONSECA. Contos reunidos, p. 460.

${ }^{9}$ FONSECA. Contos reunidos, p. 467.

10 SANTOS. Pela mão de Alice: o social e o político na pós-modernidade, p. 325.

11 MAFFESOLI. A parte do diabo: resumo da subversão pós-moderna.

12 ROSA. Grande sertão: veredas. Edição comemorativa , p.12.

13 ROSA. Grande sertão: veredas. Edição comemorativa , p. 64.

${ }^{14}$ GINZBURG. A desordem e o limite: a propósito da violência em Grande sertão: veredas, p. 8.

15 GINZBURG. A desordem e o limite: a propósito da violência em Grande sertão: veredas, p. 90.

16 GINZBURG. A desordem e o limite: a propósito da violência em Grande sertão: veredas, p. 89.
} 
narrativa] se processar, não o são". ${ }^{17} \mathrm{Em}$ busca de esclarecimento para o paradoxal hibridismo de sua identidade, o personagem assume então o papel do contador de histórias que reporta e analisa os acontecimentos dos quais participou - primeiro enquanto revolucionário depois como jagunço - na "tentativa (...) de compreender a sua própria existência e as forças que o conduziram em sua trajetória". ${ }^{18}$ Faltou-lhe, no entanto, uma percepção como a de seu duplo para que "a jagunçagem [como] forma de sociabilidade que valoriza a destruição"19 ${ }^{\prime 19}$ pudesse ter sido revertida construtivamente numa heterotopia que, através de "uma deslocação radical dentro de um mesmo lugar, o nosso, ${ }^{\prime 20}$ resultasse no Bem possível de ser alcançado pela humanidade, ou ao menos pela sociedade brasileira tomada metonimicamente pela comunidade sertaneja. Isto transcenderia a repressão estéril - deflagrada por Zé Bebelo - daquilo que não se pode recalcar: a violência.

Ela é o elemento que perpassa, em diversas modulações, o conjunto das obras analisadas a seguir, revelando-se um objeto de estudo que extrapola os limites de uma crítica puramente estética, circunscrita às especificidades do texto, por causa da abundância de conexões estabelecidas, nos casos abordados, com a identidade cultural brasileira e as estruturas de instauração do poder político no país. Numa época em que o presidente da maior potência bélica do mundo justifica suas intervenções militares no Oriente Médio com argumentos muito próximos aos que Zé Bebelo utilizou para exterminar a jagunçagem e que previsões catastróficas divulgadas a partir de relatórios científicos elaborados pela Organização das Nações Unidas fazem lembrar o alerta do Autor de Intestino grosso, censurado três décadas atrás pelo regime de exceção dos militares, a temática dessas obras se agiganta exigindo um exame minucioso cujas conclusões estão longe de serem encerradas no limite deste artigo, mas que podem contribuir com um debate irrecusável (por que não?) para a crítica literária nos dias atuais.

\section{PARTE II}

Numa leitura comparativa da representação da violência em Guimarães Rosa e Rubem Fonseca, a imagem mais nítida que se pode perceber é a da descontinuidade histórico-literária entre tais escritores. Não obstante, a raspagem do palimpsesto ficcional deste proporciona a descoberta de determinadas frestas pelas quais se entreveem vestígios culturais do sertão rosiano em sua prosa urbana. Em direção contrária, também é possível perceber, num exame prospectivo, como a obra de Rosa mimetiza certos comportamentos que encontrarão desdobramento na literatura urbana daquele que o renega. Além das óbvias imagens de descontinuidade entre tais estilos, há, portanto, imagens de permanência entre os brasis que cada um representou a seu modo.

Uma delas reafirma a ruptura fonsequiana segundo a qual "não dá mais para Diadorim, ${ }^{\prime 21}$ pois o autor considera absolutamente anacrônica uma produção literária com lastros regionalistas numa época em que o processo de urbanização se intensificava no Brasil, transformando profundamente a identidade cultural de seu povo.

No âmbito específico da violência, tal ruptura é reiterada também no sentido de que a vingança, levada a cabo pela donzela guerreira, em nome da honra do pai assassinado pelos traidores Hermógenes e Ricardão, tornou-se um paradigma há muito desqualificado

${ }^{17}$ GINZBURG. A desordem e o limite: a propósito da violência em Grande sertão: veredas, p. 62.

18 GINZBURG. A desordem e o limite: a propósito da violência em Grande sertão: veredas, p. 40.

${ }^{19}$ GINZBURG. A desordem e o limite: a propósito da violência em Grande sertão: veredas, p. 59.

20 SANTOS. Pela mão de Alice: o social e o político na pós-modernidade, p. 325.

${ }^{21}$ FONSECA. Contos reunidos, p. 468. 
pela sociedade brasileira. Trata-se de um paradigma oriundo da cultura popular explicado por Gomes e Pereira como o valor do "bom crime", o qual estabelece que "quando se violam as inter-relações básicas, é preciso matar, para reinstalar a ordem necessária". ${ }^{22}$ $\mathrm{O}$ indivíduo obediente a tal imperativo encontra-se automaticamente vinculado a uma coletividade que o envolve desde o núcleo familiar à comunidade em que habita. Neste caso, a violência exerce uma função mediadora das relações sociais, legitimada pela preservação das tradições culturais.

Esta mesma forma de mediação reaparece no conto "Entrevista", de Rubem Fonseca, porém completamente esvaziada de sentido. A protagonista da estória vinga-se da amante do marido distribuindo "vários golpes com o caco de garrafa no peito dela, com tanta força que saiu um nervo para fora, de dentro do seio". ${ }^{23}$ O esposo, em represália, esmurra a face da própria mulher e quase a deixa cega por isso. Em seguida, ele quebra os móveis da casa antes de arrastá-la pelo chão dando-Ihe pontapés na barriga, provocando um aborto. É quando o sogro e os cunhados do adúltero aparecem, espancam-no até desmaiá-lo e então cospem e urinam em seu rosto. Nada disso, porém, visa restabelecer a ordem convencional do casamento. A mulher ofendida comete um ato de violência gratuita, para usar uma expressão conhecida, dando início a uma série de agressões físicas que terminam com a sua ida ao Rio de Janeiro, onde vai prostituir-se em busca de felicidade.

A personagem define-se assim, ao fim e ao cabo, como um sujeito moderno, radicalmente individualizado, desprendido de qualquer laço coletivo e, consequentemente, desenraizado dos sólidos valores morais que outrora, na época de Diadorim, regulavam as relações de alteridade, inclusive em observância ao paradigma do "bom crime". O comportamento de $M$, adverso ao patriarcalismo das formas tradicionais de sociabilidade, acaba por desvinculá-la da coletividade que a envolvia - ao contrário, por exemplo, do que ocorre em A hora e vez de Augusto Matraga: Dionóra obedece com imenso temor a Nhô Augusto, seu marido, submetendo-se servilmente às suas ofensas, ${ }^{24}$ até o momento em que ele perde o poder oligárquico, herdado do pai. Só então ela cria coragem para envolver com outro homem, abandonando o esposo infiel e autoritário.

Sob esse viés houve então uma descontinuidade entre Rosa e Rubem, advinda da mudança paradigmática impulsionada na sociedade brasileira pelos processos de industrialização e urbanização, que, além de acarretarem uma recomposição geográfica da população do país hiperconcentrado-a em grandes cidades, também lhe agregaram um novo valor, a individualidade, com o qual o sujeito moderno emancipa-se paulatinamente dos antigos vínculos de pertencimento às tradições culturais, fontes de um sentimento comunitário responsável pela garantia da identidade.

Por outro lado, mesmo após a intensificação do processo de urbanização do país, permanece - e se intensifica - nas grandes cidades, sobretudo, uma forma de violência que pode ser definida, conforme Jaime Ginzburg, ${ }^{25}$ como um "instrumento de sobrevivência" tanto da "forma de vida jagunça", como aponta o crítico, quanto dos pivetes de Feliz ano novo. Ambos os grupos organizam-se exclusivamente para satisfazer as carências que assolam cada um de seus membros. Assim como Ginzburg observa acerca da jagunçagem, esta quadrilha também "não tem para seus membros função como forma de congregação de pessoas, no sentido humanitário. Ela se define em

${ }^{22}$ GOMES; PEREIRA. Mundo encaixado: significação da cultura popular, p. 76.

${ }^{23}$ FONSECA. Contos reunidos, p. 444-445.

${ }^{24}$ ROSA. Sagarana, p. 329.

${ }^{25}$ GINZBURG. A desordem e o limite: a propósito da violência em Grande sertão: veredas, p. 89. 
termos de uma forma política de auto-preservação coletiva, alheia à legislação do Estado". ${ }^{26}$ Percebe-se assim a continuidade de um modo de vida determinado pela exclusão social, peça integrante das estruturas do poder político no país. Impedidos de suprir as necessidades vitais básicas obedecendo à legalidade constitucional da nação, jagunços e pivetes não encontram outro meio de sobrevivência que não seja a violência. Daí "os usos de bando em armas invadir cidades"27 ou "uma casa bacana que tá dando festa", ${ }^{28}$ "arrasar o comércio", ${ }^{29}$ "assalta[r] um supermercado no Leblon", 30 "ofender as donzelas e as famílias, gozar senhoras casadas, por muitos homens, o marido obrigado a $v^{\prime \prime \prime} r^{\prime 31}$ sua esposa sendo levada para o quarto, onde além de estuprada é assassinada por Pereba. ${ }^{32}$ Tais episódios corroboram a permanência dos mesmos comportamentos, apesar das diferenças histórico-geográficas e socioculturais que distinguem os grupos em questão.

Dentre tais diferenças, uma que merece destaque é a influência dos meios de comunicação de massa que estimulam o consumo como forma de afirmação identitária do indivíduo na sociedade, galvanizando a ação criminosa dos protagonistas de Feliz ano novo como forma de reagir à concentração dos bens de consumo nas mãos duma parcela minoritária da sociedade, da qual se encontram excluídos. Isto remete ao conto "O cobrador", cujo protagonista busca inserir-se nessa camada privilegiada da sociedade exterminando o maior número possível de indivíduos bem-sucedidos em termos socioeconômicos. A ilusão de que seus atentados lhe trarão o acesso aos bens de consumo é antes uma forma desesperada de reação à violência da exclusão social do que uma ação revolucionária em prol de uma sociedade mais justa e igualitária.

Donde emerge outra descontinuidade em relação à prosa rosiana, atentando-se para o projeto utópico de Zé Bebelo com o qual pretende estender a modernidade, através da ordem e do progresso, ao sertão. Para levá-lo a cabo, a violência revela-se novamente o instrumento indispensável, justificando o extermínio da jagunçagem sob a ótica deste personagem.

Esse viés comparativo enfatiza o tom sarcástico latente em "O cobrador", que, consoante o conjunto da obra de seu autor, "espelha o paradoxo de um tempo que se nutre da desconstrução das utopias que sustentavam os sonhos de transformação do mundo". ${ }^{33}$ Tempo bem diferente do encontrado nas memórias de Riobaldo, em cujas veredas há passagem para "Os revoltosos (...) soldados de Prestes, [que] vinham de Goiás, reclamavam posse de todos animais de sela. Sei que deram fogo, na barra do Urucúia, em São Romão, aonde aportou um vapor do Governo, cheio de tropas da Bahia". ${ }^{34}$ O que faz parecer a época a qual Rubem Fonseca se reporta muito mais próxima da atualidade do que do período em que suas narrativas ora examinadas foram publicadas: os anos 1960 e 1970, período marcado politicamente pela resistência ao regime de exceção imposto pela ditadura militar - resistência cujas manifestações foram, muitas vezes, protagonizadas por grupos guerrilheiros de orientação marxista, à cuja utopia comunista Luís Carlos Prestes aderiu alguns anos após a liderança da Coluna referida por Riobaldo na citação anterior. Motivo pelo qual passou a ser novamente

${ }^{26}$ GINZBURG. A desordem e o limite: a propósito da violência em Grande sertão: veredas.

${ }^{27}$ ROSA. Grande sertão: veredas. Edição comemorativa, p. 118.

${ }^{28}$ FONSECA. Contos reunidos, p. 368.

${ }^{29}$ ROSA. Grande sertão: veredas. Edição comemorativa, p. 118.

${ }^{30}$ FONSECA. Contos reunidos, p. 366.

${ }^{31}$ ROSA. Grande sertão: veredas. Edição comemorativa, p. 118.

32 FONSECA. Contos reunidos, p. 369-370.

${ }^{33}$ FIGUEIREDO. Os crimes do texto: Rubem Fonseca e a ficção contemporânea, p. 29.

${ }^{34}$ ROSA. Grande sertão: veredas. Edição comemorativa, p. 88. (grifo nosso) 
perseguido, como tantos outros que foram torturados, exilados ou mortos pelas monstruosidades do regime.

Por outro ângulo, para além da descontinuidade observada entre a utópica revolução político-social de Zé Bebelo e a revolta socioeconômica do Cobrador, constatase uma permanência das estruturas do poder oligárquico no Brasil, que, conforme apontam os referenciais históricos das estórias em exame, atravessam o país desde a República Velha até o regime militar imposto em 1964. Cumpre asseverar que tais referenciais são indicados aqui através de dados dos textos, o que não implica desconsiderar, quanto a Grande sertão: veredas, "o apagamento proposital de datas por parte de Guimarães Rosa, que visa representar também a dimensão 'possível' e alegórica da história". ${ }^{35}$

A permanência dessas estruturas pode ser sondada no conto "Mandrake" através do reconhecimento do delegado Guedes de que seria perfeitamente plausível, durante a década de 1970, alguém como o personagem do senador Cavalcante Méier manter um bando de jagunços para defender à força os seus interesses em Alagoas, onde é um latifundiário poderoso. O que se revela uma prática tão arraigada na esfera oligárquica da sociedade que se adaptou às novas condições de sociabilidade advindas do processo urbano-industrial. Tanto que o próprio Mandrake cogita a hipótese de o Senador ter contratado um pistoleiro para executar a amante que o envolveria num escândalo potencialmente prejudicial à sua carreira política. Guedes, no entanto, adverte que "nesses não se pode confiar. A polícia põe a mão neles, enche de porrada e eles contam tudo. Não são jagunços de fazenda, protegidos pelo feudo". ${ }^{36}$ Todavia, se nas grandes cidades o sistema jagunço é ortodoxamente impraticável, a justiça privada encontra um meio de substituí-lo por algo equivalente, no caso, o próprio Mandrake, sujeito "cínico, inescrupuloso, competente. Especialista em casos de extorsão e estelionato", ${ }^{37}$ cujo "negócio é tirar as pessoas das garras da polícia". ${ }^{38}$ As pessoas que têm poder (aquisitivo) para isso, não se deve esquecer.

A permanência desses instrumentos de justiça privada confirma a interpretação de Willi Bolle, segundo a qual "Guimarães Rosa representa o funcionamento das estruturas de poder no país. Visionariamente, ele retrata uma sociedade que está se criminalizando em ampla escala e em que virtualmente todos são cooptados". ${ }^{39}$

Além disso, a promiscuidade entre a ordem e a desordem figurada nesses casos remete também à frustração dos ideais civilizadores de Zé Bebelo, com os quais pretendia modernizar o sertão fornecendo cidadania aos habitantes deste território desprivilegiado pela natureza e pelo Estado. A derrota política de sua campanha permite então enquadrá-lo, sob a ótica de José Murilo de Carvalho, na categoria de bestializado, pois aconteceu ao personagem algo semelhante ao que o sociólogo observa nas relações entre cidadãos e citadinos no Rio de Janeiro dos primeiros anos da República - regime que "se caracterizaria pela ampliação da cidadania" ${ }^{40}$ tal como o propõe Zé Bebelo. De modo que tal sistema de governo, "mesmo no Brasil, apresentou-se como o regime da liberdade e da igualdade, como o regime do governo popular". ${ }^{41}$ No entanto:

Encontramos realidade diferente. Nossa República, passado o momento inicial de esperança de expansão democrática, consolidou-se sobre um mínimo de

35 BOLLE. grandesertão.br: o romance de formação do Brasil, p. 121.

${ }^{36}$ FONSECA. Contos reunidos, p. 542.

37 FONSECA. Contos reunidos, p. 526.

38 FONSECA. Contos reunidos, p. 542.

39 BOLLE. grandesertão.br: o romance de formação do Brasil, p. 138.

40 CARVALHO. Os bestializados: o Rio de Janeiro e a República que não foi, p. 161.

${ }^{41}$ CARVALHO. Os bestializados: o Rio de Janeiro e a República que não foi, p. 161. 
participação eleitoral, sobre a exclusão do envolvimento popular no governo. Consolidou-se sobre a vitória da ideologia liberal pré-democrática, darwinista, reforçadora do poder oligárquico. As propostas alternativas de organização do poder, a do republicanismo radical, a do socialismo e mesmo a do positivismo, derrotadas, foram postas de lado. A cidade do Rio de Janeiro, por sua vez, não apresentava as características da cidade burguesa onde se desenvolveu a democracia moderna. $O$ peso das tradições escravista e colonial obstruía o desenvolvimento das liberdades civis, ao mesmo tempo que viciava as relações dos citadinos com o governo. Era uma cidade (...) em que desmoronava a ordem antiga sem que se implantasse a nova ordem burguesa, o que equivale a outra maneira de afirmar a inexistência das condições para a cidadania política. ${ }^{42}$

Zé Bebelo parece então ter subestimado o peso destas tradições. Por ter acreditado que poderia subvertê-las eliminando um dos instrumentos de manutenção do poder oligárquico - a jagunçagem - o personagem reflete a forma de pensamento do bestializado, que "era quem levasse a política a sério". ${ }^{43}$ Quer dizer, trata-se de uma ideologia que idealiza um sistema abstrato em detrimento de uma realidade social considerada pior do que as virtualidades do sistema. Esta sua visão de mundo, no entanto, é reformulada depois da derrota de seu projeto de instauração do novo sistema de poder político. Consoante Luiz Roncari:

Zé Bebelo reconhece um erro, que redefinirá o seu papel futuro no sertão: o de ter tentado combater o sertão como um todo, em vez de procurar discernir dentro dele os aliados ou as forças positivas que também o habitavam, como reconhecia ser agora Joca Ramiro. (...) Era este o meio de se ultrapassar o sertão, não lutando contra ele, mas encontrando nele as forças para um governo, uma ordem e uma política distintas daquelas das forças dominantes particularistas, as dos "chefes políticos", às quais homens como Ricardão e Hermógenes submetiam-se sem restrições e se transformavam nas encarnações dos seus desmandos. Talvez fosse isso que Zé Bebelo quisesse dizer, quando afirmava que "só se sai do sertão é tomando conta dele a dentro". O seu erro tinha sido o de não ter reconhecido que no sertão havia também uma força de civilização e boa vontade, com a qual deveria ter sabido poder contar, como a que prevalecia com o julgamento: "prova de que vós nossos jagunços do Norte são civilizados de calibre". Na sua consciência e fala tais forças tinham origem e representavam forças históricas bastante concretas. ${ }^{44}$

Essa tomada de consciência revela ao próprio personagem o fato de que ele não conhecia o oponente em sua inteireza, não sabia, portanto, o que estava combatendo. Esse não saber o torna de certo modo inocente, na acepção etimológica do termo que remonta diretamente a esta constatação do Cobrador: "Eu não sabia o que queria, não buscava um resultado prático, meu ódio estava sendo desperdiçado. Eu estava certo nos meus impulsos, meu erro era não saber quem era inimigo e por que era inimigo. Agora sei, Ana me ensinou. ${ }^{\prime 45}$ Delineia-se aí uma continuidade entre os personagens, consistente numa visão míope da complexidade sócio-histórica do meio no qual estão inseridos. O foco dessa percepção limitada aponta então para uma divisão maniqueísta da sociedade, o que condiciona os projetos de aniquilação do outro, classificado como a

42 CARVALHO. Os bestializados: o Rio de Janeiro e a República que não foi, p. 161-162. (grifo nosso)

43 CARVALHO. Os bestializados: o Rio de Janeiro e a República que não foi, p. 160.

44 RONCARI. O Brasil de Rosa: O amor e o poder, p. 336.

45 FONSECA. Contos reunidos, p. 504. (grifos nosso) 
encarnação do mal que precisa ser eliminado. Ambos desconhecem alternativas, menos violentas e mais construtivas, de transformação social. Não sabem delas. Por isso são inocentes.

Inocência que também se encontra na personalidade paradoxal de Hermógenes, sobre a qual Riobaldo comenta: "meu pensamento constante querendo entender a natureza dele, virada diferente de todas, a inocência daquela maldade." ${ }^{46} \mathrm{O}$ narrador perscruta assim o não saber que impulsiona Hermógenes à perversidade, "feito lobisomem". ${ }^{47}$ Quanto a isso, cabe citar uma explicação de Jaime Ginzburg:

A imagem estereotipada do "lobisomem" sugere uma mudança do humano para o meio humano ou não humano, caracterizando como que uma passagem do bom comportamento civil para a crueldade guerreira. Essa imagem levaria a crer que o homem, em condições normais, não seria cruel; apenas quando lobo-homem, lobisomem. Essa concepção supõe uma distinção clara entre homens e bestas ferozes. Ela não se sustenta frente ao medo do homem humano, ${ }^{48}$ medo da crueldade especificamente humana. Riobaldo é perturbado pela ferocidade estranha e fora de controle dos jagunços; então é o homem humano, e não o não humano, que provoca o terror. ${ }^{49}$

Não obstante, levando-se em conta a ferocidade dos seres não humanos como algo definidor de sua natureza selvagem - em contraposição à racionalidade humana cumpre destacar aqui o caráter instintivo desses seres que atuam de modo inconsciente, alheio à razão e, portanto, inocente. Sob esse viés, a imagem da entidade híbrida, que é o lobisomem, apresenta-se bastante significativa para a hipótese ora em demonstração, pois pode ser entendida como um caso extremo de inocência na medida em que o ser humano, sob a forma enfeitiçada do referido monstro, revela o caráter instintivo de sua natureza agindo de modo inconsciente. Algo que - sobretudo para a civilização eurocêntrica de lastro humanista - é uma monstruosidade que deve ser recalcada. Civilização que contraditoriamente, sob as ordens de Zé Bebelo, tenta ser imposta no sertão através das monstruosidades da guerra - legitimada oficialmente em nome do "bem" (no caso, da ordem e do progresso) - mas que, no entanto, pode ser também interpretada como mais uma forma de etnocídio praticada pelo ocidentalismo dominante, consoante explicação de Michel Maffesoli:

O "bem", com efeito, é a justificação última do messianismo judaico-cristão. As teorias de emancipação e o universalismo modernos, que constituem suas mais recentes manifestações, também se escoram nesse princípio básico. Foi em seu nome que as diferentes inquisições fizeram seu trabalho sujo. Em seu nome é que foram cometidos todos os etnocídios culturais e justificados os imperialismos econômico e político. É mais uma vez, em seu nome que se decreta o que deve ser vivido e pensado, como se deve viver e pensar, e que se declara tabu esta maneira de viver ou aquele objeto de análise. Este universalismo foi a justificação de todos os colonialismos, dos etnocídios culturais que constituíram a marca da ocidentalização do mundo a partir do fim do século XIX. ${ }^{50}$

Desse modo, o etnocídio cultural deflagrado por Zé Bebelo é entendido como uma tentativa de imposição de uma forma de sociabilidade incompatível com o jaguncismo

${ }^{46}$ ROSA. Grande sertão: veredas. Edição comemorativa, p. 213. (grifo nosso)

${ }^{47}$ ROSA. Grande sertão: veredas. Edição comemorativa, p. 214.

${ }^{48}$ A referência bibliográfica da edição citada por Ginzburg é: Grande sertão: veredas. Rio de Janeiro: J. Olympio, 1978. p. 307.

${ }^{49}$ GINZBURG. A desordem e o limite: a propósito da violência em Grande sertão: veredas, p. 28.

${ }^{50}$ MAFFESOLI. A parte do diabo: resumo da subversão pós-moderna, p. 12. 
então considerado tabu, sendo a figura inocentemente perversa de Hermógenes um de seus maiores emblemas. Sob essa perspectiva, nos discursos políticos do "chefe cidadão", ${ }^{1}$ Sr. José Rebelo Adro Antunes, caberiam perfeitamente bem aquelas conhecidas palavras: "não dá mais para Diadorim". ${ }^{52}$

No entanto, sua campanha foi derrotada. O jaguncismo enquanto forma de sociabilidade repudiada pela ordem burguesa não foi plenamente recalcado no sertão. Pelo contrário. Devido, entre outras coisas, à secular política de exclusão social do Estado brasileiro, a jagunçagem - cujo elemento essencial é uma "criatura paga para crimes, impondo o sofrer no quieto arruado dos outros, matando e roupilhando"153 - encontrou condições favoráveis à sua permanência, adaptando-se facilmente à atual conjuntura dos grandes centros urbanos do país, ora sob a forma do crime organizado, ora no sadismo semelhante à ferocidade de Hermógenes - manifestado por pivetes como os do conto "Feliz Ano Novo" ou pelo atropelador de "Passeio noturno". Quer dizer então que desde o sertão "arredado do arrocho de autoridade" ${ }^{\prime 54}$ até a cidade grande, submersa em "uma necessidade de regimentalização próxima da organização do formigueiro", ${ }^{55}$ a continuidade desse comportamento sádico confirma, antecipadamente, a tese sociológica de Machado da Silva, segundo a qual:

o ordenamento social produzido pela criminalidade organizada cancela a relação de alteridade que tem sido pensada como o fundamento da vida coletiva. De fato (...) a interação entre os criminosos e entre estes e suas vítimas ou grupos subordinados baseia-se na negação do outro como igual, reduzindo-o à condição de objeto. Além dos problemas filosóficos que pode significar uma vida social sem intersubjetividade, em termos mais concretos isto põe em questão as formas assumidas pelo individualismo contemporâneo e os quadros de referência que têm sido elaborados para sua análise. ${ }^{56}$

As possibilidades de cruzamento entre a jagunçagem e a atual configuração do crime organizado nas grandes cidades brasileiras é matéria extensa que extrapola os limites deste trabalho. Cabe, contudo, para concluir sem a pretensão de se encerrar a questão, propor uma reflexão que encare o individualismo contemporâneo como sustentáculo da inocência daquelas maldades.

\section{CONCLUSÃO}

De uma forma bastante sutil, Rubem Fonseca problematiza o comportamento atomizado da individualidade contemporânea nos versos de "Os inocentes" (publicados originalmente no livro Lúcia McCartney. Trata-se de um cadáver putrefeito devolvido à praia pelo mar. Em seguida:

Banhistas instalam barracas longe da coisa morta, logo envolvida por enorme círculo de areia, indiferença, asco.

Policial limpa suor da testa, olha gaivota, céu azul.

Afinal rabecão: corpo carregado.

Espaço branco vazio cercado pelo colorido das barracas, lenços, biquínis, chapéus, toalhas, por todos os lados.

${ }^{51}$ ROSA. Grande sertão: veredas. Edição comemorativa, p. 354.

52 FONSECA. Contos reunidos, p. 468.

53 ROSA. Grande sertão: veredas. Edição comemorativa, p. 201.

54 ROSA. Grande sertão: veredas. Edição comemorativa, p. 5.

55 FONSECA. Contos reunidos, p. 467.

56 SILVA. Criminalidade violenta: por uma nova perspectiva de análise, p. 18. 
Chega família:

"Olha, parece que reservaram lugar para nós". ${ }^{57}$

Quem chega por último ri melhor, sem saber do que havia se passado enquanto estava ausente, e logo se aproveita do espaço vazio em meio à multidão.

Há nesse texto um diálogo implícito com o poema "Inocentes do Leblon", de Drummond:

Os inocentes do Leblon

não viram o navio entrar.

Trouxe bailarinas?

trouxe imigrantes?

trouxe um grama de rádio?

Os inocentes, definitivamente inocentes, tudo ignoram,

mas a areia é quente, e há um óleo suave

que eles passam nas costas, e esquecem. ${ }^{58}$

Ambos informam sobre o cotidiano burguês e a indiferença das classes remediadas ou mais abastadas - indiferença necessária ao usufruto dos pequenos prazeres da vida. Ignorar tudo aquilo que possa perturbar-lhes o bem-estar é, em última análise, a estratégia de sobrevivência definitivamente descompromissada com a coletividade que as envolve. Bem-estar que, em casos extremos, provém do atropelamento letal de um pedestre indefeso, do latrocínio ou do estupro de um outro qualquer, reduzido à condição de objeto. $O$ que não exime tais executores da inocência observada nos banhistas acima, pois tais assassinos ignoram relações intersubjetivas de sociabilidade. O sadismo desses personagens pode ser então entendido como algo lúdico, se visto de dentro, considerando-se a falta de sentimento humanitário congênita ao individualismo contemporâneo; mas, por outro ângulo, também é possível considerá-lo algo "devastador e injustificável, se visto de fora, considerando as vítimas [indefesas], que pagam o preço de, por acaso, não serem parte do grupo armado", 59 consoante a concepção do sistema jagunço formulada por Jaime Ginzburg, que serve igualmente de arcabouço teórico para compreender o comportamento dos pivetes fonsequianos, protagonistas de Feliz ano novo.

Cumpre reiterar, portanto, que qualificar os agentes dessas manifestações de violência como inocentes implica uma construção discursiva advinda da necessidade de se entenderem as raízes do problema no Brasil, ou quais seriam os motivos causadores das agressões físicas examinadas neste artigo. Para que tal argumentação adquirisse credibilidade buscou-se, então, elaborá-la a partir do ponto de vista dos homicidas em questão, os quais, à exceção de Riobaldo, encaram seus atos como algo habitual, como ir à praia tomar banho de sol para os inocentes do Leblon.

Em Rubem Fonseca isso se torna perceptível pelo efeito da "linguagem de superfície" com a qual os protagonistas de seus contos narram os seus crimes mais cruéis com a impassibilidade típica de um inocente que não sabe da coisa morta, sobre cuja memória está assentado, porque ela era um outro qualquer - reduzido à condição de objeto, como explica Machado da Silva. ${ }^{60}$

Em Guimarães Rosa, esse aspecto encontra-se latente na condenação de Riobaldo aos costumes jagunços e nos relatos de casos como o de Aleixo - um "homem de maiores ruindades calmas que já se viu. (...) Um dia, só por graça rústica, ele matou um

57 FONSECA. Contos reunidos, p. 349.

58 DRUMMOND. Sentimento do mundo, p. 35.

59 GINZBURG. A desordem e o limite: a propósito da violência em Grande sertão: veredas, p. 14.

60 SILVA. Criminalidade violenta: por uma nova perspectiva de análise, p. 18. 
velhinho que por lá passou, desvalido rogando esmola"; ${ }^{61}$ - e de Valtêi e seus pais, cujo "prazer feio de diversão" ${ }^{\prime 62}$ consiste em variadas formas de agressão física, inclusive o homicídio.

A inocência dessas maldades é bastante proveitosa àqueles que a detêm, revelando-se um mecanismo de mediação social obediente à ordem dos afetos, inda mais quando atrelado à violência.

Dessa forma, para melhor compreender esse mecanismo deve-se aproximá-lo da imagem de cordialidade abordada no ensaio seminal de Sérgio Buarque de Holanda (2007). Parte-se aqui do pressuposto de que "o conceito é usado 'no seu sentido exato e estritamente etimológico'", como explicou recentemente Silviano Santiago: "Cordial tem sua origem mais longínqua em cor(d)-, 'coração', e mais recente no latim medieval, cordialis, que significa 'relativo ao coração."'163

Dentre os vários reflexos que Sérgio Buarque observa a partir desse elemento intrínseco à brasilidade, talvez o mais pertinente à hipótese ora em tela seja o de que a religiosidade brasileira constituiu-se a partir de um "culto que só apelava para os sentimentos e os sentidos e quase nunca para a razão e a vontade". ${ }^{64}$ Tem-se com isso um elemento formador de uma identidade cultural que prescinde de autoconsciência para existir, diferentemente da noção de sujeito construída pela ideologia cartesiana. É embasado na inocência dessa identidade não pensante que Riobaldo pontifica sobre o comportamento jagunço: "Não podendo entender a razão da vida, é só assim que se pode ser vero jagunço", ${ }^{65}$ ou vero pivete, vale acrescentar.

A imagem do homem cordial abrange, portanto, a identidade desses jagunços, pivetes e outros inocentes (como o Cobrador, o Aleixo, o atropelador de "Passeio noturno" e os pais de Valtêi), englobando em si diversas práticas de relações de alteridade, tais como as pautadas pela obediência à moral da honra e da vingança; as que deflagram guerra contra aquilo que representa o mal a ser isolado da sociedade; ou ainda aquelas cujo modo de entretenimento também pode ser qualificado, em termos jurídicos, como homicídio doloso. Mesmo nesse último caso, porém, seus agentes não sabem da destruição que deixam para trás. Dessa forma, a noção de inocência - tomada etimologicamente - é proposta como suplementar à de cordialidade, o que se sustenta no seguinte esclarecimento do próprio Sérgio Buarque acerca de sua interpretação sobre o caráter cordial da sociedade brasileira: "A inimizade pode ser tão cordial como a amizade, nisto que uma e outra nascem do coração." ${ }^{\prime 66}$ Rearticulada por Silviano Santiago, tal explicação torna-se ainda mais pertinente a essa argumentação, conforme se lê a seguir:

Por ser ambivalente, a cordialidade nunca significa polidez; tem, no entanto e paradoxalmente, de significá-la para que seja possível o convívio social entre brasileiros e entre brasileiros e estrangeiros. A comunidade nacional e cosmopolita, que intriga o ensaísta [Sérgio Buarque], não pode ser um agrupamento de indivíduos ferozes e/ou bondosos. O brasileiro tem de buscar a harmonia entre os opostos, ser cordial.

Impôs-se ao ensaísta a constatação de que existe um nexo, uma ponte que liga os sentimentos opostos da ambivalência. Através do nexo entre brasileiros, ou através da ponte que nos liga ao estrangeiro, é que a

\footnotetext{
${ }^{61}$ ROSA. Grande sertão: veredas, p. 5.

62 ROSA. Grande sertão: veredas, p. 11.

63 SANTIAGO. As raízes e o labirinto da América Latina, p. 242.

64 HOLANDA. O "homem cordial", p. 150.

65 ROSA. Grande sertão: veredas. Edição comemorativa, p. 520.

66 HOLANDA. O "homem cordial", p. 205.
} 
contribuição brasileira para a civilização não será nem pura bondade nem pura maldade. Assim sendo e entre nós, "a atitude polida consist[e] precisamente em uma espécie de mímica deliberada de manifestações que são espontâneas no 'homem cordial'". A mímica é deliberada e, ao mesmo tempo, espontânea. ${ }^{67}$

Diante disso, destaca-se em primeiro lugar o fato de que essa espontaneidade, enquanto sinônimo de naturalidade, corrobora a leitura de Guimarães Rosa sobre seus próprios personagens, a qual vale a pena ser novamente citada, acrescida de um período:

A gente do sertão, os homens de meus livros (...) vivem sem consciência do pecado original; portanto, não sabem o que é o bem e o que é o mal. Em sua inocência, cometem tudo o que nós chamamos "crimes", mas que para eles não o são. Alguma coisa deste modo de pensar se conservou até mesmo na justiça de muitos países civilizados. Pense na distinção entre assassinato premeditado e homicídio irrefletido, ou no que os franceses chamam "crime passional", o assassinato por ciúmes etc. ${ }^{68}$

Esse raciocínio, por sua vez, remete àquele juízo fonsequiano segundo o qual seria inadequado qualificar certos homicídios como criminosos devido à falta de consciência por parte de quem os executou. ${ }^{69}$

Com base nas conexões possíveis entre essas interpretações, propõe-se então que, das maneiras de ser do homem cordial, a da inocência seja a imagem que contribui para compreender as diversas formas através das quais a violência se manifesta enquanto cordialidade, ou seja, é incorporada no cotidiano social brasileiro, afetando não só as estratégias de sobrevivência das camadas excluídas das benesses do Estado e do sistema capitalista, como também os recursos utilizados na instituição do poder público no país. Pode-se dizer, contudo, que, em certos episódios das narrativas históricas abordadas por Sérgio Buarque e Silviano Santiago, ou naqueles examinados neste texto, a harmonia indicada por Silviano parece sofrer um desequilíbrio que a faz pender para o lado puramente maléfico, tornando o convívio social entre brasileiros altamente destrutivo e, portanto, cronicamente inviável - para fazer alusão ao filme dirigido por Sérgio Bianchi (Agravo Produções, 1999). Desse modo, a acepção de homem cordial como conciliador de contrários pode até ser desmistificada, mas não se aparta dela, no entanto, "a inocência daquela maldade" que Riobaldo reputa a Hermógenes ${ }^{70}$ e se estende aqui tanto aos homens do sertão, além dos jagunços, quanto às pessoas empilhadas na cidade, além dos pivetes. Inocência que define o brasileiro como homem cordial, mesmo na condição de executor de certas monstruosidades.

Assim, se em partes "não dá mais para Diadorim"71 porque "de legítimo leal pouco sobra"772 do sertão, Rubem Fonseca tem tudo a ver com Guimarães Rosa, porque tanto um quanto outro são escritores pornográficos, conforme acepção do autor de "Intestino grosso", cujos "livros estão cheios de miseráveis sem dentes". ${ }^{73}$

Sob esse viés, a prosa fonsequiana é inserida na extensa tradição de retratos do Brasil, à qual Grande sertão: veredas foi anexado pelo estudo crítico de Willi Bolle, não

67 SANTIAGO. As raízes e o labirinto da América Latinha, p. 243-244.

${ }^{68}$ LORENZ. Diálogo com Guimarães Rosa, p. 58.

${ }^{69}$ FONSECA. Contos reunidos.

${ }^{70}$ ROSA. Grande sertão: veredas. Edição comemorativa, p. 213.

${ }^{71}$ FONSECA. Contos reunidos, p. 468.

72 ROSA. Grande sertão: veredas. Edição comemorativa, p. 17.

73 FONSECA. Contos reunidos, p. 461. 
obstante tratar-se de uma denominação "que se aplica basicamente a ensaios de história e ciências sociais". ${ }^{74}$

O que torna tal interpretação plausível, em relação a ambos os autores em tela, é, basicamente, o produto de três fatores: a denúncia da condição dos "outros, [dos] molambos de miséria, (...) que não possu[em] o respeito de roupas de vestir (...) e não [têm] quase nenhum dente" $;{ }^{75}$ a reflexão sobre as estruturas de poder instauradas no país, que determinam a perpetuação desse enorme desequilíbrio econômico-políticosocial; e a tentativa de elaborar, a partir dos dados fornecidos pelos fatores antecedentes, uma construção estético-discursiva que abranja a identidade cultural brasileira em sua complexa heterogeneidade. Rosa e Fonseca revelam-se assim intérpretes do Brasil, cujas produções literárias suplementam o diversificado conhecimento produzido a fim de decifrar este país-enigma.

Abstract:

This is a study of Grande sertão: veredas, by Guimarães Rosa, and of the tales "Intestino grosso", "Entrevista", "Feliz Ano Novo", "Mandrake", "O cobrador" and "Os inocentes", by Rubem Fonseca, whose objective is to show that the focused narratives contain violence that suggests innocence in the characters that perform them. Thus, they should be classified as monstrosities rather than as criminal actions, if one takes into account that the inherent perversity to the monsters is part of the non knowledge that impels their acts.

Keywords: Guimarães Rosa; Rubem Fonseca; violence

Referências

ANDRADE, Carlos Drummond de. Sentimento do mundo. Rio de Janeiro: MEDIAfashion, 2008. p. 35. v. 4. (Coleção Folha Grandes Escritores Brasileiros)

BOLLE, Willi. grandesertão.br: o romance de formação do Brasil. São Paulo: Duas Cidades; Ed. 34, 2004.

CAMINHA, Pero Vaz de. A Carta. Disponível em: <http://www.dominiopublico.gov.br/download/texto/ua000283.pdf >. Acesso em: 13 jun. 2008.

CARVALHO, José Murilo de. Os bestializados: o Rio de Janeiro e a República que não foi. São Paulo: Companhia das Letras, 1997.

FIGUEIREDO, Vera Lúcia Follain de. Os crimes do texto - Rubem Fonseca e a ficção contemporânea. Belo Horizonte: Ed. UFMG, 2003. (Coleção Humanitas)

${ }^{74}$ BOLLE. grandesertão.br: o romance de formação do Brasil, p. 23.

${ }^{75}$ ROSA. Grande sertão: veredas. Edição comemorativa, p. 350-354. 
FONSECA, Rubem. Contos reunidos. Org. Boris Schnaiderman. São Paulo: Companhia das Letras, 1995.

FONSECA, Rubem. Romance negro, Feliz Ano Novo e outros contos. Seleção de textos: Maura Sardinha. Rio de Janeiro: Ediouro, 1996.

GINZBURG, Jaime. A desordem e o limite: a propósito da violência em Grande sertão: veredas. Dissertação de mestrado em Literatura Brasileira apresentada à Faculdade de Filosofia, Letras e Ciências Humanas da Universidade de São Paulo. São Paulo: 1993. Versão Word for Windows.

GOMES, Núbia P. de Magalhães; PEREIRA, Edimilson de Almeida. Mundo encaixado: significação da cultura popular. Belo Horizonte: Mazza Edições; Juiz de Fora: UFJF, 1992. p. 73-102.

HOLANDA, Sérgio Buarque de. O "homem cordial". In: . Raízes do Brasil. São Paulo: Companhia das Letras, 2007. p.146-151.

LORENZ, Günter. Diálogo com Guimarães Rosa. In: ROSA, João Guimarães. Guimarães Rosa: ficção completa. Rio de Janeiro: Nova Aguilar, 1994. p. 27-61. v. I. 2 v.

MAFFESOLI, Michel. A parte do diabo: resumo da subversão pós-moderna. Trad. Clóvis Marques. Rio de Janeiro: Record, 2004.

ROSA, João Guimarães. Grande sertão: veredas. Rio de Janeiro: Nova Fronteira, 1988.

ROSA, João Guimarães. Grande sertão: veredas. Edição comemorativa. Rio de Janeiro: Nova Fronteira, 2006. Acompanhado do catálogo e DVD da Exposição Grande sertão: veredas, dirigida por Bia Lessa.

ROSA, João Guimarães. Sagarana. Rio de Janeiro: J. Olympio, 1980.

RONCARI, Luiz. O Brasil de Rosa: o amor e o poder. São Paulo: Ed. Unesp, 2004.

SANTIAGo, Silviano. As raízes e o labirinto da América Latinha. Rio de Janeiro: Rocco, 2006.

SANTOS, Boaventura de Souza. Pela mão de Alice: o social e o político na pósmodernidade. São Paulo: Cortez, 2000.

SILVA, L. A. Machado da. Criminalidade violenta: por uma nova perspectiva de análise. Revista de Sociologia e Política, n. 13, p.115-124; Cidadania e Violência, nov. 1999. Curitiba, UFPr. Versão Word for Windows. 